\title{
The expansion of a patient tracer programme to identify and return patients loss to follow up at a large HIV clinic in Trinidad
}

\author{
R. Jeffrey Edwards ${ }^{1,2^{*}}$, Nyla Lyons², Wendy Samaroo-Francis², Leon-Omari Lavia², Isshad John², Selena Todd ${ }^{2}$,
} Jonathan Edwards ${ }^{2}$ and Gregory Boyce ${ }^{2}$

\begin{abstract}
Background: Patients who default from HIV care are usually poorly adherent to antiretroviral treatment which results in suboptimal viral suppression. The study assessed the outcomes of retention in care and viral suppression by expansion of an intervention using two patient tracers to track patients lost to follow up at a large HIV clinic in Trinidad.

Methods: Two Social Workers were trained as patient tracers and hired for 15 months (April 2017-June 2018) to call patients who were lost to follow up for 30 days or more during the period July 2016-May 2018 at the HIV clinic Medical Research Foundation of Trinidad and Tobago.

Results: Over the 15-month period, of the of 2473 patients who missed their scheduled visits for 1 month or more, 261 (10.6\%) patients were no longer in active care - 89 patients dead, 65 migrated, 55 hospitalized, 33 transferred to another treatment clinic and 19 incarcerated. Of the remaining 2212 patients eligible for tracing, 1869 (84.5\%) patients were returned to care, 1278 (68.6\%) were virally unsuppressed (viral load $>200$ copies $/ \mathrm{ml}$ ) and 1727 (92.4\%) were re-initiated on ART. Twelve months after their return, 1341 (71.7\%) of 1869 patients were retained in care and 1154 (86.1\%) of these were virally suppressed. Multivariate analysis using logistic regression showed that persons were more likely to be virally suppressed if they were employed (OR, 1.39; 95\% Cl 1.07-1.80), if they had baseline CD4 counts $<200$ cells $/ \mathrm{mm}^{3}(\mathrm{OR}, 1.71 ; 95 \% \mathrm{Cl} 1.26-2.32)$ and if they were retained in care at 12 months $(\mathrm{OR}, 2.48 ; 95 \%$ $\mathrm{Cl} 1.90-3.24)$. Persons initiated on ART for $4-6$ years (OR, 3.09; 95\% Cl 1.13-8.48,), 7-9 years (OR, 3.97; $95 \% \mathrm{Cl} 1.39-$ $11.31)$, $>10$ years (OR, 5.99; $95 \% \mathrm{Cl} 1.74-20.64$ were more likely to be retained in care.
\end{abstract}

Conclusions: Patient Tracing is a feasible intervention to identify and resolve the status of patients who are loss to follow up and targeted interventions such as differentiated care models may be important to improve retention in care.

Keywords: Patient tracing, HIV, Intervention, Differentiated care

\section{Background}

The use of anti-retroviral therapy (ART) which effectively suppresses the HIV viral load of patients results in reduced HIV transmission, reduced $\mathrm{CD} 4+\mathrm{T}$ cell

*Correspondence: jeffreye2000@gmail.com

${ }^{2}$ Medical Research Foundation of Trinidad and Tobago, 7 Queen's Park East, Port of Spain, Trinidad and Tobago

Full list of author information is available at the end of the article depletion and improved reconstitution of the immune system thereby transforming HIV into a chronic, manageable disease [1-4]. Thus lifelong management of patients with HIV infection requires long term retention on ART [5] which may prove quite challenging as the barriers to retention in HIV care should to be identified and addressed so that the individual and public health benefits of viral suppression can be achieved [6-9]. A

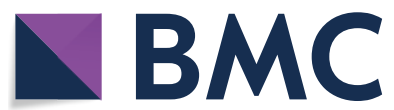

(c) The Author(s) 2021. This article is licensed under a Creative Commons Attribution 4.0 International License, which permits use, sharing, adaptation, distribution and reproduction in any medium or format, as long as you give appropriate credit to the original author(s) and the source, provide a link to the Creative Commons licence, and indicate if changes were made. The images or other third party material in this article are included in the article's Creative Commons licence, unless indicated otherwise in a credit line to the material. If material is not included in the article's Creative Commons licence and your intended use is not permitted by statutory regulation or exceeds the permitted use, you will need to obtain permission directly from the copyright holder. To view a copy of this licence, visit http://creativeco mmons.org/licenses/by/4.0/. The Creative Commons Public Domain Dedication waiver (http://creativecommons.org/publicdomain/ zero/1.0/) applies to the data made available in this article, unless otherwise stated in a credit line to the data. 
systematic review of patient retention in antiretroviral programmes describing 39 cohorts of patients showed that $25 \%$ of patients were no longer on ART 24 months after initiation of treatment [10]. Patients who are lost to follow up (LTFU) and non-adherent to ART are at increased risk for HIV transmission, HIV disease progression and subsequent mortality $[1,2,11,12]$, thus it is important to bring those patients with missed appointments back into care $[13,14]$.

The twin island republic of Trinidad and Tobago are the southernmost islands of the Caribbean and comprise a single nation with a population of approximately 1.36 million (2019 mid-year estimate). The first cases of AIDS were reported in 1983 among gay/bisexual men [15] and by 1985 , there was a transition to predominantly heterosexual transmission of HIV [16]. Antiretroviral therapy, subsidized by the government, became available in 2002 and there are approximately 11,000 PLHIV in Trinidad \& Tobago with an estimated 27\% PLHIV unengaged in care/lost to follow up/not actively on ART treatment [17].

The Medical Research Foundation of Trinidad and Tobago (MRFTT), the largest HIV clinic in Trinidad and Tobago and the Southern Caribbean, recently conducted a 6-month pilot which assessed the feasibility of a patient tracing programme for HIV that re-engaged in care those patients who missed their clinic appointments and the data from this study was previously reported [18]. In this pilot programme, two social workers were trained as patient tracers and of 1058 patients who missed their scheduled visits for 1 month or more, 192 were no longer in active care (deceased, incarcerated, hospitalized, migrated or transferred to another clinic) and 866 were eligible for patient tracing [18]. Of the 866 patients, 589 $(68 \%)$ were successfully contacted and returned to care [18].

The data and outcomes of this pilot study assisted in allocation of programme resources for targeted interventions to reduce lost to follow up and increase patient retention in HIV care through a tailored package of HIV services to better serve the needs patients enrolled in HIV care [19] to include those patients who regularly miss their clinic appointments, youth, non-virally suppressed patients and the prison population. The MRFTT clinic implemented models of Differentiated Service Delivery (DSD) [20] using a client driven approach to increase patient retention in HIV care, ART adherence and viral suppression. For example, the clinic operating hours were extended during the weekdays [18] and Saturday morning sessions targeting patients who regularly miss their clinic appointments and those newly initiated on ART. Patient/Peer Advocates [18] were trained to mentor and assist patients to overcome the barriers to
ART adherence and retention during dedicated clinic visits [18]. A once per month prison outreach program was implemented to improve ART retention among persons living with HIV who were incarcerated. The MRFTT also implemented a monthly youth focused clinic targeting young persons living with HIV aged $18-25$ years with a package of services to include text message reminders and enhanced psychosocial care to retain youth PLHIV on ART.

With these differentiated care services available for patients attending the clinic, the purpose of this study was to evaluate the outcomes of an expanded intervention using patient tracers to find patients lost to follow up from the Medical Research Foundation HIV clinic, and monitor their retention and viral suppression 12 months after their return to care.

\section{Methods}

This was a retrospective study to track patients who missed their scheduled clinic visit for over 1 month and were deemed lost to follow up at the HIV clinic, Medical Research Foundation of Trinidad and Tobago (MRFTT). As of June 30, 2018, a total of 6486 patients were reported to be enrolled active in care at the HIV clinic. The patient tracing methods at the MRFTT are described elsewhere [18]. The patient tracers (social workers) spent 15 months (April 2017-June 2018), 5 days per week, contacting patients via phone calls who missed their scheduled visits and did not return to the clinic for over 30 days during the period July 2016-May 2018 and these patients were given an appointment to return to care. Once a patient was re-engaged in care, a HIV viral load (VL) was done at that point, the patient would be re-initiated/started on ART and viral loads (VL) were repeated every 3-6 months and the last VL 12 months after re-engagement in care was recorded for the study.

\section{Inclusion criteria}

Any patient attending the HIV clinic who missed their clinic visit for 30 days or more (lost to follow up) during the period July 2016-May 2018.

\section{Exclusion criteria}

Any patient attending the HIV clinic who missed their clinic visit for less than 30 days (missed appointments) during the period July 2016-May 2018.

Any patient attending the HIV clinic who did not miss clinic visits during the period July 2016-May 2018.

The source population was the patients attending the HIV clinic, MRFTT during the period July 2016-May 2018. Generally, one patient tracer would follow up with one particular patient so that a relationship could be established and trust built up. "Treat all" started in 
September 2017 at the MRFTT and all patients who returned to care were offered or restarted on ART and followed up bi-weekly, then monthly, then 3 monthly and finally every 6 months once they were stable on ART and their HIV viral loads were suppressed.

All study protocols and procedures were reviewed and approved the University of the West Indies, Campus Research Ethics Committee, St. Augustine, Trinidad. De-identified patient data were extracted for analysis and this was cleaned and organised into an excel spreadsheet database which was imported into the Statistical Package for Social Sciences (SPSS version 25). The data were compiled to a flowchart to examine all the patients who returned to the clinic including those patients who were lost to follow up. The sociodemographic characteristics of the patients were examined by descriptive analyses and the outcomes were stratified by selected descriptive features. The analysis consisted of a Pearson's chi-square test in order to determine if a statistically significant relationship existed between selected descriptive features and the 12-month outcomes of retention in care and viral suppression. Multivariate analysis using logistic regression was then carried out on the variables that had a statistically significant association with the outcomes to identify the influence of these variables on the 12-month outcomes of retention in care and viral suppression. Both the start-up and implementation costs of the interventions were assessed.

Retention in care was defined as a patient in care and having at least two documented clinic visits (physician visit or/pharmacy medication pick-up or laboratory tests) separated by $\geq 90$ days during a calendar year. Viral suppression was defined as a viral load of less than 200 copies $/ \mathrm{ml}$.

\section{Results}

Figure 1 shows the flow of patient outcomes through the study over the 15 month period, April 2017-June 2018. Of the sample of 2473 patients who missed their scheduled visits for 1 month or more, it was determined that $261(10.6 \%)$ patients were no longer in active care. These included, 89 patients who were confirmed dead, 65 migrated, 55 hospitalized, 33 transferred to another treatment clinic and 19 incarcerated. Of the remaining 2212 patients eligible for tracing, 227 (10.3\%) patients could not be reached up until the end of the study period and 1985 (89.7\%) patients were contacted and rescheduled to return to clinic within the same week or their earliest availability. Of those who were reached, 116 did not show up for their rescheduled appointments, thus 1869 (84.5\%) of 2212 patients eligible for patient tracing were successfully returned to care (Fig. 1).

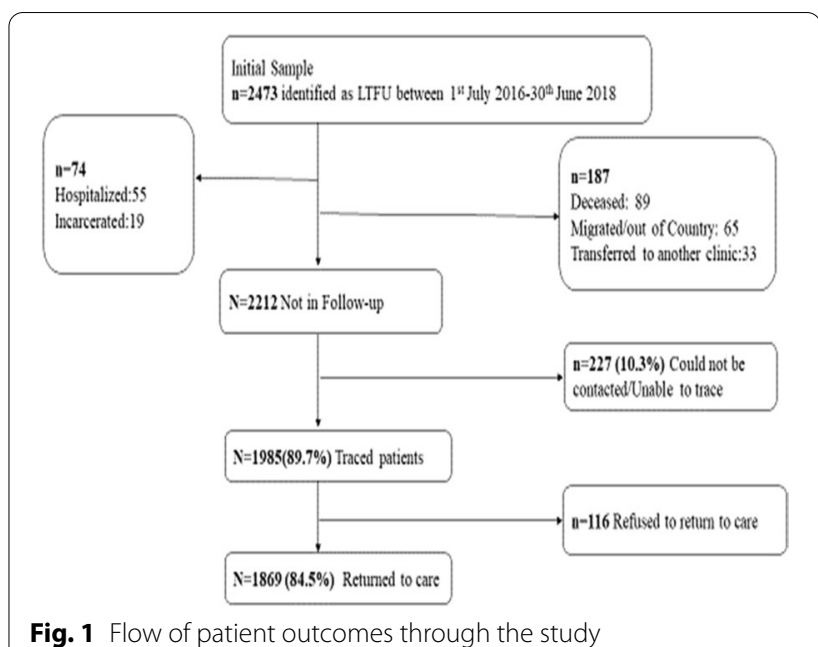

Table 1 shows the descriptive characteristics of the 1869 patients returned to care, there were 951 (50.9\%) males and 918 (49.1\%) females, age range 18-90 years, mean age 43.6 years. There were 21 (1.1\%) Female Sex Workers (FSW), 1638 (87.6\%) heterosexuals, 221 (11.8\%) and $10(0.6 \%)$ self- identified as men who have sex with men (MSM) and lesbians respectively, 985 (71.1\%) were employed, 504 (27\%) who ever used crack/cocaine/ marijuana and 1278 (68.6\%) were virally unsuppressed (VL $>200$ copies/ml).

Figure 2 shows the return to care cascade and tracing outcomes at the MRFTT, of the 1869 patients returned to care, 1727 (92.4\%) were re-initiated/started on ART and 12 months after re-engagement in care, 1341 (71.7\%) of 1869 patients were retained in care and 1154 (86.1\%) of these were virally suppressed $(\mathrm{VL}<200$ copies/ml).

Table 2 shows the 12-month retention in care and 12-month viral suppression by selected descriptive characteristics. Statistically significant associations for retention in care at 12 months were seen for those persons who were employed $(\mathrm{p}=0.01)$, those with baseline CD4 counts $<200$ cells $/ \mathrm{mm}^{3}(\mathrm{p}=0.033)$ and those who had initiated ART for longer periods of time $(\mathrm{p}<0.001)$. Statistically significant associations for viral load suppression at 12 months were seen for those who were employed $(p=0.001)$, those who ever used drugs such as marijuana/crack/cocaine $(\mathrm{p}=0.007)$ those with baseline CD4 counts $<200$ cells $/ \mathrm{mm}^{3}(\mathrm{p}=0.005)$, those who had initiated ART for longer periods of time $(\mathrm{p}<0.001)$ and those who were retained in care at 12 months $(\mathrm{p}<0.001)$.

Multivariate analysis using logistic regression (Table 3) showed persons were more likely to be retained in care after 12 months if they were employed (OR, 1.41; 95\% CI 1.06-1.88) and those who initiated ART for 4-6 years (OR, 3.09; 95\% CI 1.13-8.48), 
Table 1 Baseline characteristics of patients LTFU on re-entry to care

\begin{tabular}{|c|c|}
\hline Descriptive statistic & $\begin{array}{l}\text { Total } \\
(n=1869)\end{array}$ \\
\hline \multicolumn{2}{|l|}{ Sex } \\
\hline Male & $951(50.9 \%)$ \\
\hline Female & $918(49.1 \%)$ \\
\hline Mean age & 43.6 years \\
\hline Age range & $18-90$ years \\
\hline \multicolumn{2}{|l|}{ Ethnicity $(n=1621)$} \\
\hline African & $1168(72.1 \%)$ \\
\hline East Indian & $118(7.3 \%)$ \\
\hline Mixed/other & $335(20.7 \%)$ \\
\hline \multicolumn{2}{|l|}{ Sexual orientation } \\
\hline Heterosexual & $1638(87.6 \%)$ \\
\hline MSM & $221(11.8 \%)$ \\
\hline Lesbian & $10(0.6 \%)$ \\
\hline Female sex worker (FSW) & $21(1.1 \%)$ \\
\hline \multicolumn{2}{|l|}{ Employment status ( $n=1386)$} \\
\hline Employed & 985 (71.1\%) \\
\hline Unemployed & $401(28.9 \%)$ \\
\hline \multicolumn{2}{|c|}{ Drug use (crack/cocaine/marijuana) } \\
\hline Drug use & $504(27.0 \%)$ \\
\hline Non-drug use & $1365(73.0 \%)$ \\
\hline \multicolumn{2}{|c|}{ Viral suppression on re-entry to care $(n=1862)$} \\
\hline Viral Load <200 copies/ml & $584(31.4 \%)$ \\
\hline Viral Load > 200 copies/ml & $1278(68.6 \%)$ \\
\hline \multicolumn{2}{|l|}{ Baseline CD4 count ( $n=1859)$} \\
\hline$C D 4<200$ & $620(33.4 \%)$ \\
\hline CD4 > 200 & $1239(66.6 \%)$ \\
\hline \multicolumn{2}{|l|}{ Years on ART } \\
\hline Never initiated ART & $75(4.0 \%)$ \\
\hline$\leq 3$ years & $1027(54.9 \%)$ \\
\hline 4-6 years & $396(21.2 \%)$ \\
\hline 7-9 years & $308(16.5 \%)$ \\
\hline$\geq 10$ years & $63(3.4 \%)$ \\
\hline
\end{tabular}

7-9 years (OR, 3.97; 95\% CI 1.39-11.31), > 10 years (OR, 5.99; 95\% CI 1.74-20.64 compared to those who never initiated ART.

Multivariate analysis using logistic regression (Table 3) showed persons were more likely to be virally suppressed at 12 months if they were employed (OR, 1.39; 95\% CI 1.07-1.80), if they had baseline CD4 counts $\leq 200$ cells $/ \mathrm{mm}^{3}$ (OR, 1.71; 95\% CI 1.26-2.32) and if they were retained in care at 12 months (OR, 2.48; 95\% CI 1.90-3.24).

The pilot phase of the programme took place over the 6-month period April-September 2017 and of the 866 patients were eligible for patient tracing, 589 (68\%) were successfully contacted and returned to care [18] as compared to $1869(84.5 \%)$ of 2212 patients eligible for patient tracing who were successfully returned to care in the extended programme $(\mathrm{p}<0.001)$. After re-engagement in care for 12 months in the pilot programme, of the 589 patients returned to care, 439 $(74.5 \%)$ of these were retained in care and $376(85.6 \%)$ of these were virally suppressed as compared to 1341 $(71.8 \%)$ of 1869 patients who were retained in care $(\mathrm{p}=0.89)$ and $1154(86.1 \%)$ of these were virally suppressed $(\mathrm{VL}<200$ copies $/ \mathrm{ml})$ in the expanded programme $(\mathrm{p}=0.93)$.

Both the start-up and implementation costs of the intervention were assessed (Table 4). The main cost of the intervention was the salary of the two patient tracers, who were employed in pilot phase of programme, initially for 6 months and then in extended programme for 15 months, and the costs of program management which included clerical support, office expenses, services and supplies and bus tickets, a small amount of petty cash (\$100 USD/month), snack vouchers and high protein drinks which were given to patients in need (Table 4). The start-up costs i.e. the first month of intervention was $\$ 5757$ USD per month. The total cost of the intervention in the pilot programme was $\$ 28,107.48$ USD and in the extended programme was $\$ 68,338.20$ USD. In pilot programme, 589 patients were returned to care at an estimated cost of $\$ 47.72$ USD per patient compared to 1869 patients were returned to care in the extended programme (Table 4) at an estimated to be $\$ 36.56$ USD per patient.

\section{Discussion}

During the 15 month extended programme, two patient tracers working 5 days per week were able to determine the status of 1910 (86.3\%) of 2212 patients who were lost to follow up and were eligible for patient tracing. The intervention resulted in returning 1869 (84.5\%) of 2212 patients to care as compared to 589 of $866(68 \%)$ patients successfully contacted and returned to care in the 6 -month pilot programme $(\mathrm{p}<0.001)$. Thus the effect of the intervention improved over time as more patients were successfully returned to care which may be attributed to the enhanced efficiency of the patient tracing programme as the patient tracers became more proficient at calling patients who missed their clinic appointments and getting them back into care; due to cultivated relationships between the patient tracers and staff from other treatment sites so that patient transfers among sites were more readily ascertained and the MRFTT started a prison programme in January 2018 so that incarcerated patients could be readily identified. In addition, "treat all' was introduced in September 2017, before this ART was indicated for patients at MRFTT whose CD4 counts 


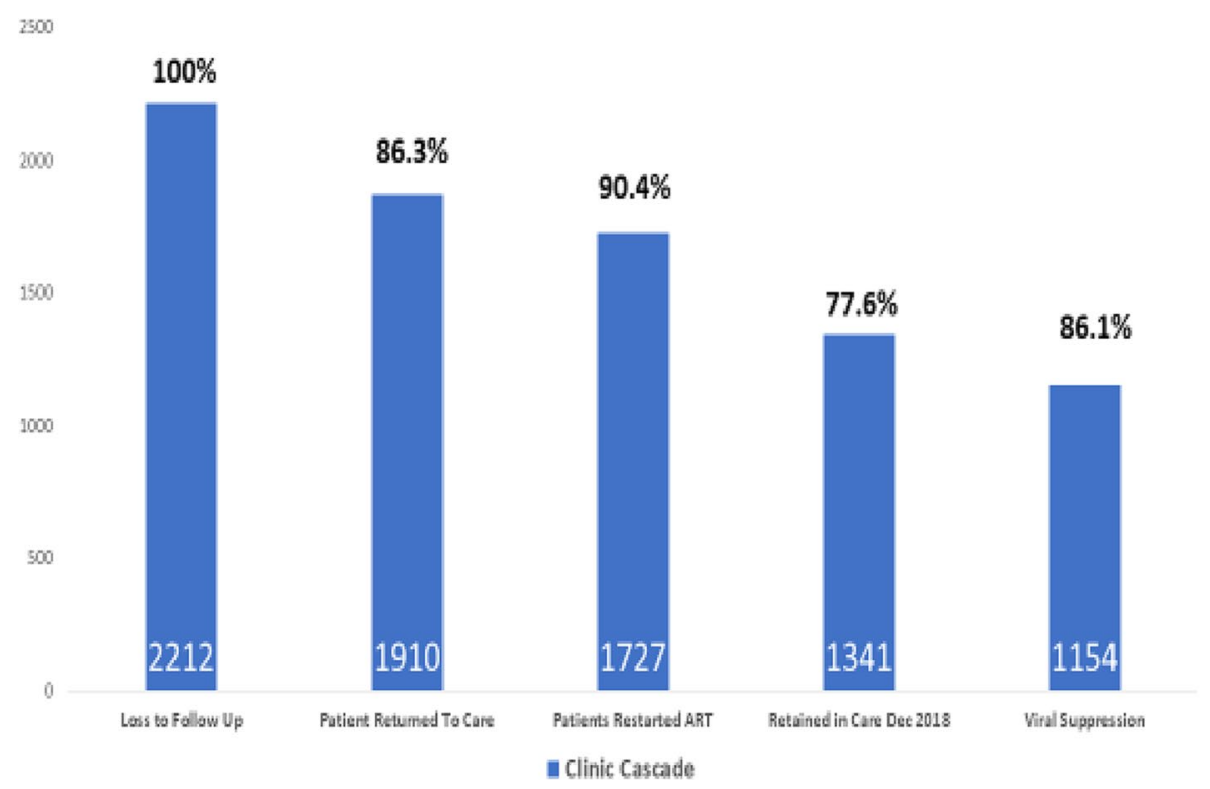

Fig. 2 The return to care cascade at the MRFTT, at the end 2018

fell below 350 cells $/ \mathrm{mm}^{3}$, so some patients defaulted from clinic as they claimed no treatment was offered to them as their CD4 cell count was "stable". During the phone calls, the patient tracers explained to the patients the benefits of ART and assured them that once they returned to clinic, ART would be initiated/reinitiated.

Patient tracing programmes have been shown to be effective in determining the status of patients who missed their clinic appointments [14], however there have been mixed results in returning patients to care [21-23]. In a study by Tweya et al. in Malawi, of 1158 patients who missed their clinic visits and were located by tracing, $74 \%$ returned to care [21]. Of patients missing clinic appointments in Lusaka, Zambia, Krebs et al. [22] successfully traced 430 (54\%) of 789 patients, however only one patient returned to care for every 18 home visits made [22] and in a community based antiretroviral therapy programme in Uganda, of 579 patients sampled for tracing, $61(12.7 \%)$ patients returned to care [23]. In our study, the intervention resulted in 1869 (84.5\%) of 2212 patients eligible for tracing being returned to care.

Patients who miss their clinic appointments often have unsuppressed and transmissible viral loads and are generally not included in the ascertainment of the HIV Treatment Cascade of the HIV clinic [24]. Of the 1869 patients returned to care, 1278 (68.6\%) were virally unsuppressed, 1727 (92.4\%) were re-initiated/started on ART, and after 12 months, $1341(77.6 \%)$ of these were retained in care and 1154 (86.1\%) of these were virally suppressed. In the study by Krentz et al. [24], it was found that patients who missed their clinic visits and returned to care had high rates of unsuppressed viral loads (54.5\%) especially if the patients were out of care for more than a year [24]. Our study showed that patients who were retained in care after 12 months were more likely to be virally suppressed (OR, 2.48; 95\% CI 1.90-3.24) compared to those with suboptimal retention in care and multiple studies have demonstrated this [7, 25, 26]. In addition, Yehia et al. [27] analyzed 35,433 adult patients attending 18 HIV clinics in the USA between 2006-2011 and found that the association between retention in care and viral suppression was more strongly associated with patients with $C D 4 \leq 200$ cells $/ \mathrm{mm}^{3}$ [27] which may suggest a more high-quality patient-provider relationship in patients with advanced disease $[27,28]$. In our study, it was found that persons were more likely to be virally suppressed at 12 months if they had baseline CD4 counts $\leq 200$ cells $/ \mathrm{mm}^{3}$ (OR, 1.71; 95\% CI 1.26-2.32) however the results were not statistically significant for retention in care at 12 months. There are mixed results in patients with $\mathrm{CD} 4<200$ cells $/ \mathrm{mm}^{3}$ and subsequent viral suppression as a systematic review by Lailulo et al. [29] done to identify factors associated with ART treatment failure showed that the likelihood of treatment failure was significantly higher in patients with CD4 $<200$ cells $/ \mathrm{mm}^{3}$ (OR, 4.82; 95\% CI 2.44-9.52) in resource limited areas perhaps due to HIV related opportunistic infections, increased pill burdens and the potential to develop increased drug toxicity in patients with advanced disease on multiple medications [29].

The International Labour Organization (ILO) conducted a systematic review of 23 studies involving 6674 PLHIV assessing adherence rates and found that persons 
Table 2 Selected descriptive characteristics after 12-months of retention in care and viral suppression

\begin{tabular}{|c|c|c|c|c|c|c|}
\hline Descriptive Statistic & $\begin{array}{l}\text { Retention in Care at } \\
12 \text { months } \\
\mathrm{N}=1341\end{array}$ & $\begin{array}{l}\text { OR } \\
95 \% \mathrm{Cl}\end{array}$ & $p$ value & $\begin{array}{l}\text { Viral Suppression } \\
\text { at } 12 \text { months } \\
V L<200 \text { copies/ml } \\
N=1154\end{array}$ & $\begin{array}{l}\text { OR } \\
95 \% \mathrm{Cl}\end{array}$ & $p$ value \\
\hline Sex & & 1.13 & 0.244 & & 0.85 & 0.09 \\
\hline Male & $671(50.0 \%)$ & & & $605(52.4 \%)$ & & \\
\hline Female & $670(50.0 \%)$ & $0.92-1.38$ & & $549(47.6 \%)$ & $0.71-1.03$ & \\
\hline Ethnicity $(n=1621)$ & & & 0.065 & & & 0.583 \\
\hline African & $827(71.3 \%)$ & Ref & & $706(71.2 \%)$ & Ref & \\
\hline East Indian & $78(6.7 \%)$ & $\begin{array}{l}0.829 \\
0.50-1.37\end{array}$ & & $\begin{array}{l}72(7.3 \%) \\
213(21.5 \%)\end{array}$ & $\begin{array}{l}0.910 \\
0.55-1.50\end{array}$ & \\
\hline Mixed/other & $255(22.0 \%)$ & $\begin{array}{l}1.19 \\
0.84-1.67\end{array}$ & & & $\begin{array}{l}1.18 \\
0.85-1.65\end{array}$ & \\
\hline Sexual orientation & & 0.936 & 0.669 & & 0.804 & 0.124 \\
\hline Heterosexual & $1178(87.8 \%)$ & $0.69-1.27$ & & $1022(88.6 \%)$ & $0.61-1.06$ & \\
\hline MSM & $158(12.2 \%)$ & & & $132(11.4 \%)$ & & \\
\hline Employment status ( $n=1386$ ) & & $\begin{array}{l}1.38 \\
1.08-1.77\end{array}$ & 0.011 & & $\begin{array}{l}1.51 \\
1.19-1.91\end{array}$ & 0.001 \\
\hline Employed & $716(73.1 \%)$ & & & $603(74.6 \%)$ & & \\
\hline Unemployed & $264(26.9 \%)$ & & & $205(25.4 \%)$ & & \\
\hline Drug use (crack/cocaine/marijuana) & & $\begin{array}{l}0.81 \\
0.65-1.02\end{array}$ & 0.071 & & $\begin{array}{l}0.751 \\
0.61-0.93\end{array}$ & 0.007 \\
\hline Drug use & $346(75.2 \%)$ & & & $286(24.8 \%)$ & & \\
\hline Non-drug use & $995(78.5 \%)$ & & & $868(75.2 \%)$ & & \\
\hline Baseline CD4 $(n=1859)$ & & $\begin{array}{l}1.27 \\
1.02-1.58\end{array}$ & 0.033 & & $\begin{array}{l}1.33 \\
1.09-1.63\end{array}$ & 0.005 \\
\hline$C D 4 \leq 200$ & $154(29.6 \%)$ & & & $412(35.7 \%)$ & & \\
\hline CD4 > 200 & $466(70.4 \%)$ & & & $741(64.3 \%)$ & & \\
\hline Years on ART & & & $<0.001$ & & & $<0.001$ \\
\hline Never initiated ART & $13(1.0 \%)$ & & & $7(0.6 \%)$ & & \\
\hline$\leq 3$ years & $740(55.2 \%)$ & & & $643(55.7 \%)$ & & \\
\hline 4-6 years & $296(22.1 \%)$ & & & $276(23.9 \%)$ & & \\
\hline $7-9$ years & $243(18.1 \%)$ & & & $198(17.2 \%)$ & & \\
\hline$\geq 10$ years & $49(3.7 \%)$ & & & $30(2.6 \%)$ & & \\
\hline Retention in care after 12 months & & & & & $\begin{array}{l}3.18 \\
2.58-3.19\end{array}$ & $<0.001$ \\
\hline Retained & & & & $933(80.8 \%)$ & & \\
\hline Not retained & & & & $221(19.2 \%)$ & & \\
\hline
\end{tabular}

who were employed at the time of the study were more likely to have achieved optimal ART adherence (OR, 1.39; 95\% CI 1.13-1.71) than those who were unemployed [30]. It was found that unemployment, particularly in resource limited settings was linked to the inability of persons to afford related health services, medications and nutritional support which may lead to poor treatment adherence, low viral suppression and ART failure [30]. Our study supports these findings as persons who were employed were more likely to be retained in care at 12 months (OR, 1.41; 95\% CI 1.06-1.88) and more likely to be virally suppressed (OR, 1.39; 95\% CI 1.07-1.80).
In the study by Rosen and Ketlhapile in South Africa, 20 of 97 patients (21\%) who missed clinic visits were returned to care by patient tracing at a cost of $\$ 432$ USD per patient, which was quite expensive and unsustainable [31]. Table 4 shows the total cost of the intervention in the pilot programme was $\$ 28,107.48$ USD and in the extended programme was $\$ 68,338.20$ USD. During the pilot phase, a total of 589 patients were returned to care at an estimated cost of $\$ 47.72$ USD per patient returned compared to 1869 patients were returned to care in the extended programme at an estimated to be $\$ 36.56$ USD per patient returned. Thus, once the programme was 
Table 3 Results of multivariate logistic regression the variables that had a statistically significant association with the outcomes retention in care and viral suppression

\begin{tabular}{|c|c|c|c|c|}
\hline \multirow[t]{2}{*}{ Descriptive statistic } & \multicolumn{2}{|c|}{$\begin{array}{l}\text { Retained in care } \\
N=1341\end{array}$} & \multicolumn{2}{|c|}{$\begin{array}{l}\text { Viral suppression } \\
V L<200 \text { copies } / \mathrm{ml} \\
N=1154\end{array}$} \\
\hline & $\begin{array}{l}\text { OR } \\
95 \% \mathrm{Cl}\end{array}$ & $95 \% \mathrm{Cl}$ & $\begin{array}{l}\text { OR } \\
95 \% \mathrm{Cl}\end{array}$ & $95 \% \mathrm{Cl}$ \\
\hline $\begin{array}{l}\text { Employment status }(n=1386) \\
\text { Employed } \\
\text { Unemployed }\end{array}$ & 1.41 & $1.06-1.88$ & 1.39 & $1.07-1.80$ \\
\hline $\begin{array}{l}\text { Drug use (crack/cocaine/marijuana) } \\
\text { Drug use } \\
\text { Non-drug use }\end{array}$ & & & 0.823 & $0.66-1.67$ \\
\hline $\begin{array}{l}\text { Baseline CD4 }(n=1859) \\
\text { CD4 } \leq 200 \\
\text { CD4 }>200\end{array}$ & 0.886 & $0.65-1.21$ & 1.71 & $1.26-2.32$ \\
\hline Years on ART & & & & \\
\hline Never initiated ART & Reference & & Reference & \\
\hline$\leq 3$ years & 2.12 & $0.80-5.60$ & 1.71 & $0.38-7.76$ \\
\hline $4-6$ years & 3.09 & $1.13-8.48$ & 1.35 & $0.29-6.29$ \\
\hline 7-9 years & 3.97 & $1.39-11.31$ & 1.39 & $0.29-6.62$ \\
\hline$\geq 10$ years & 5.99 & $1.74-20.64$ & 0.68 & $0.12-3.76$ \\
\hline $\begin{array}{l}\text { Retention in care after } 12 \text { months } \\
\text { Retained } \\
\text { Not retained }\end{array}$ & & & 2.48 & $1.90-3.24$ \\
\hline
\end{tabular}

Table 4 Estimated costs of returning patients to care at MRFTT April 2017-June 2018

\begin{tabular}{|c|c|c|c|c|c|}
\hline \multirow[t]{2}{*}{ Category } & \multirow[t]{2}{*}{ Item } & \multicolumn{2}{|c|}{ Startup costs } & \multicolumn{2}{|l|}{ Implementation costs } \\
\hline & & \# Units & $\begin{array}{l}\text { Initial costs/ } \\
\text { month one }\end{array}$ & $\begin{array}{l}\text { Recurring costs/over } \\
5 \text { months }\end{array}$ & $\begin{array}{l}\text { Recurring } \\
\text { costs/over } \\
14 \text { months }\end{array}$ \\
\hline \multirow[t]{2}{*}{ Personnel salaries } & Patient tracers & 2 & $\$ 3,582.08$ & $\$ 17,910.40$ & $\$ 50,149.12$ \\
\hline & Program management & 1 & $\$ 700$ & $\$ 3500$ & $\$ 9800$ \\
\hline \multirow[t]{3}{*}{ Equipment } & Laptop & 2 & $\$ 491$ & $\$ 0.00$ & $\$ .00$ \\
\hline & Cell phones & 2 & $\$ 188$ & $\$ 940$ & $\$ 2632$ \\
\hline & Workstations & 2 & $\$ 296$ & $\$ 0.00$ & $\$ 0.00$ \\
\hline Contractual & Training & 1 & $\$ 500$ & $\$ 0.00$ & $\$ 0.00$ \\
\hline Subtotal & & & $\$ 5757.08$ & $\$ 22,350.40$ & $\$ 62,581.12$ \\
\hline \multicolumn{4}{|c|}{ Total programme costs (startup costs + implementation costs) } & $\begin{array}{l}\$ 28,107.48 \\
\text { Over } 6 \text { months }\end{array}$ & $\begin{array}{l}\$ 68,338.20 \\
\text { Over } 15 \text { months }\end{array}$ \\
\hline
\end{tabular}

launched and running efficiently it was cheaper than in the first few months of establishment and the high yield of patients returned to care (84.5\%) demonstrated its feasibility and that the programme can be sustainable.

To improve the efficiency of the patient tracing intervention, it is recommended that Trinidad and Tobago (with a population of approximately 1.36 million inhabitants) invest in a National Health Management
Information System (HMIS) to link and track HIV cases/ patients who transfer to other treatment facilities/clinics which would result in enhanced tracking and monitoring of patients across sites. The inability to track patients who have transferred to other treatment facilities obfuscates inferences about retention in care. Improved reporting of deaths and linking the national death registry to a HIV case surveillance HMIS can also be effective in validating 
the status of patients not active in care and lost to follow up [31] as well as strengthening active HIV case surveillance in hospitals and in the prisons to assist in identifying patients who are hospitalized and incarcerated.

As in the pilot programme, the three most common barriers to re engagement in care are, (1) patients not remembering their appointments, (2) patients not getting time off from work to attend their clinic appointments, and (3) patients' fear of being seen attending the HIV clinic [18]. To address these barriers the MRFTT began offering differentiated services (DSD) by extending the clinic/evening hours for patients who were employed and could not get time off from work. The extended/evening clinic provided a patient friendly environment [18] and expedited care to reduce patients waiting times. Patients with financial challenges were provided with bus tickets and meal vouchers to address transportation barriers that impacted their ability to attend clinic appointments.

The ability of the patient tracers to identify and counsel patients and successfully reintegrate them into HIV care further highlights the effectiveness of the Patient Tracing intervention. Patient tracers as trained social workers provided counselling to both treatment experienced and naive patients assisting them to overcome the barriers to ART reinitiation and/or initiation which is critical component of treat all strategy at the MRFTT. The study found that the number of years since ART initiation increased the likelihood of patients being retained in care after the 12-month period compared to patients who never initiated ART. Patients who were on ART had a higher likelihood of retention in care compared to those not initiated on ART. The results of the analysis demonstrated a higher likelihood for patient retention in care as time since ART initiation increased-hence underscoring the relationship between early ART initiation and retention in care after missed clinic visits. Of the 1869 patients returned to care, 1727 (92.4\%) were re-initiated/started on ART, and after 12 months, 1341 (77.6\%) of these were retained in care and 1154 (86.1\%) of these were virally suppressed. Given these outcomes, the Patient Tracing Programme was critical in reducing treatment interruptions which if left unattended may lead to high levels of viremia with attendant risks of increasing HIV transmission, the potential for drug resistance, the development of opportunistic infections [32], subsequent hospitalization and high costs to the health care system [33].

One of the limitations of the study is the difficulty in tracking patients' VL over time, given the crosssectional approach used. This approach may underestimate the VL burden given the changing nature of VL suppression over time [24]. Another limitation is that some patients may have returned to care after the study concluded or may have transferred to other clinics closer to their homes to reduce transportation costs [31], these factors make it challenging to effectively track patient retention in care in care at any given point in time.

Another limitation of the study is the use of a retrospective study design given that only sociodemographic and clinical characteristics data collected as part of routine program reporting were included in the analysis and therefore limiting the comparability of results across similar studies. Also, the data used in the analysis were reported either at baseline or last observed at the time of data extraction. This may also present a bias given that patients may have fallen in and out of care over the period of the analysis-hence making it difficult to measure continuous retention in HIV care.

\section{Conclusions}

Patient Tracing is a feasible and effective intervention to identify and resolve the status of patients who miss clinic appointments, re-engage and retain them in care. In this study, patient tracers as social workers provided enhanced psychosocial support assisting patients to overcome the barriers to ART initiation and/or re-initiation, retention in continuous care, and to achieve and maintain viral suppression. To enhance patient tracing outcomes, targeted interventions are needed to ensure early ART initiation and differentiated care interventions to address client specific barriers as these may improve retention in care and viral suppression. A longitudinal study design will provide additional opportunities to track the long-term effect of differentiated care interventions over time.

\section{Abbreviations}

ART: Antiretroviral therapy; DSD: Differentiated service delivery; EPR: Electronic patient records; HMIS: Health management information system; LTFU: Lost to follow up; MRFTT: Medical Research Foundation of Trinidad and Tobago.

\section{Acknowledgements}

The investigators thank the staff of the Medical Research Foundation of Trinidad and Tobago for their support during the study.

\section{Authors' contributions}

Study design and operation: RJE, NL, WSF. Follow up and assessments: RJE, IJ, ST, GB. Statistical analysis: LOL, NL. Manuscript preparation: RJE, NL, WSF, IJ, ST, $J E, G B$. We affirm that all authors contributed to the manuscript. All authors read and approved the final manuscript.

\section{Funding}

The study received financial support from the President's Emergency Fund for AIDS Relief (PEPFAR) through a grant to the Trinidad Tobago Ministry of Health, Program Number CDC-RFA-GH16-1608. The funder had no role in the study design, data collection, data analysis or writing of the report. 


\section{Availability of data and materials}

The datasets used and/or analyzed during the study are available from the corresponding author (RJE) on reasonable request.

\section{Declarations}

\section{Ethics approval and consent to participate}

The study protocol was reviewed and approved by the institutional review board of the University of the West Indies, St. Augustine Trinidad.

\section{Consent for publication}

Not applicable-The manuscript does not contain data from any individual person.

\section{Competing interests}

The authors declare they have no competing interests.

\section{Author details}

${ }^{1}$ Department of Paraclinical Sciences, Faculty of Medical Sciences, University of the West Indies, St Augustine, Trinidad and Tobago. ${ }^{2}$ Medical Research Foundation of Trinidad and Tobago, 7 Queen's Park East, Port of Spain, Trinidad and Tobago.

Received: 8 July 2020 Accepted: 8 April 2021

Published online: 23 April 2021

\section{References}

1. Quinn TC. HIV epidemiology and the effects of antiviral therapy on longterm consequences. AIDS. 2008;22(Suppl 3):S7-12. https://doi.org/10. 1097/01.aids.0000327510.68503.e8.

2. Cohen MS, Chen YQ, McCauley M, Gamble T, Hosseinipour MC, Nagalingeswaran K, Fleming TR, et al. Prevention of HIV-1 infection with early antiretroviral therapy. N Engl J Med. 2011;365(6):493-505. https://doi.org/ 10.1056/NEJMoa1105243 (Epub 2011 Jul 18).

3. Deeks SG, Lewin SR, Havlir DV. The end of AIDS: HIV infection as a chronic disease. Lancet. 2013;382(9903):1525-33. https://doi.org/10.1016/S01406736(13)61809-7.

4. Autran B, Carcelaint G, Li TS, Gorochov G, Blanc C, Renaud M, Durali M, Mathez D, Calvez V, Leibowitch J, Katlama C, Debré P. Restoration of the immune system with anti-retroviral. Therapy Immunol Lett. 1999;66(13):207-11. https://doi.org/10.1016/s0165-2478(98)00159-x.

5. Bisson GP, Stringer JS. Lost but not forgotten-the economics of improving patient retention in AIDS treatment programs. PLoS ONE. 2009. https://doi.org/10.1371/journal.pmed.1000174.

6. Holtzman CW, Brady KA, Yehia BR. Retention in care and medication adherence: current challenges to antiretroviral therapy success. Drugs. 2015;75(5):445-54. https://doi.org/10.1007/s40265-015-0373-2.

7. Giordano TP, Gifford AL, White AC, et al. Retention in care: a challenge to survival with HIV infection. Clin Infect Dis. 2007;44(11):1493-9.

8. Garcia de Olalla P, Knobel H, Carmona A, Guelar A, Löpez-Colomes J, Caylä JA. Impact of adherence and highly active antiretroviral therapy on survival in HIV-infected patients. J Acquir Immune Defic Syndr. 2002;30(1):105-10.

9. Edwards RJ, Cyrus E, Bhatt C, Lyons N, Lavia LO, Boyce G. Viral suppression among persons living with HIV in Trinidad \& Tobago: Implications for targeted prevention programmes. Glob Public Health. 2019;14(11):1569-77. https://doi.org/10.1080/17441692.2019.1633379.

10. Fox MP, Rosen S. Patient retention in antiretroviral therapy programs up to three years on treatment in sub-Saharan Africa, 2007-2009: systematic review. Trop Med Int Health. 2010;15(s1):1-15. https://doi.org/10.1111/j. 1365-3156.2010.02508.x.

11. Bangsberg DR, Perry S, Charlebois ED, et al. Non-adherence to highly active antiretroviral therapy predicts progression to AIDS. AIDS. 2001;15(9):1181-3.

12. Hogg RS, Heath K, Bangsberg D, et al. Intermittent use of triple-combination therapy is predictive of mortality at baseline and after 1 year of follow-up. AIDS. 2002;16(7):1051-8.
13. Thomson KA, Cheti EO, Reid T. Implementation and outcomes of an active defaulter tracing system for HIV, prevention of mother to child transmission of HIV (PMTCT), and TB patients in Kibera, Nairobi, Kenya. Trans R Soc Trop Med Hyg. 2011;105(6):320-6. https://doi.org/10.1016/j. trstmh.2011.02.011.

14. Geng EH, Gliddin DV, Emenyonu N, Musinguzi N, Bwana MB, Neilands TB, Martin JN. Tracking a sample of patients lost to follow-up has a major impact on understanding determinants of survival in HIVinfected patients on antiretroviral therapy in Africa. Trop Med Int Health. 2010;15(1):63-9. https://doi.org/10.1111/j.1365-3156.2010.02507.x.

15. Bartholomew C, Raju CC, Jankey N. The acquired immune deficiency syndrome in Trinidad. A report on two cases. West Indian Med J. 1983;32(3):177-80.

16. Cleghorn FR, Jack N, Murphy JR, Edwards J, Mahabir B, Paul R, White F, Bartholomew C, Blattner WA. HIV-1 prevalence and risk factors among sexually transmitted disease clinic attenders in Trinidad. AIDS. 1995;9(4):389-94

17. UNAIDS/AIDSinfo. Country Factsheet Trinidad and Tobago 2019. UNAIDS. Retrieved from Trinidad and Tobago | UNAIDS.

18. Jeffrey Edwards R, Lyons N, Bhatt C, Samaroo-Francis W, Hinds A, Cyrus E. Implementation and outcomes of a patient tracing programme for HIV in Trinidad and Tobago . Glob Public Health. 2019;14(11):1589-97. https:// doi.org/10.1080/17441692.2019.1622759.

19. Okeke NL, Ostermann J, Thielman NL. Enhancing linkage and retention in HIV care: a review of interventions for highly resourced and resourcepoor settings. Curr HIV/AIDS Rep. 2014;11(4):376-92. https://doi.org/10. 1007/s11904-014-0233-9.

20. The International AIDS Society Differentiated care for HIV: a decision framework for Antiretroviral Therapy Delivery. Geneva, Switzerland; 2016. http://www.differentiatedcare.org/Portals/0/adam/Content/yS6M-GKB5E Ws_uTBHk1C1Q/File/Decision\%20Framework.pdf

21. Tweya H, Gareta D, Chagwera F, Ben-Smith A, Mwenyemasi J, Chiputula F, Boxshall M, Weigel R, Jahn A, Hosseinipour M, Phiri S. Early active followup of patients on antiretroviral therapy (ART) who are lost to follow-up: the "Back-to-Care" project in Lilongwe, Malawi. Trop Med Int Health. 2010;15(Suppl 1):82-9. https://doi.org/10.1111/j.1365-3156.2010.02509.x.

22. Krebs DW, Chi BH, Mulenga Y, Morris M, Cantrell RA, Mulenga L, et al. Community-based follow-up for late patients enrolled in a district-wide programme for antiretroviral therapy in Lusaka, Zambia. AIDS Care. 2008:20:311-7. https://doi.org/10.1080/09540120701594776.

23. Alamo ST, Colebunders R, Ouma J, Sunday P, Wagner G, Wabwire-Mangen F, Laga M. Return to normal life after AIDS as a reason for lost to followup in a community-based antiretroviral treatment program. J Acquir Immune Defic Syndr. 2012;60(2):e36-45. https://doi.org/10.1097/FTD. Ob013e3182526e6a.

24. Krentz HB, Vu Q, Gill MJ. The impact of "Churn" on plasma HIV burden within a population under care. Open Forum Infect Dis. 2019;6(6):ofz203. https://doi.org/10.1093/ofid/ofz203.

25. Mugavero MJ, Westfall AO, Zinski A, et al. Measuring retention in HIV care: the elusive gold standard. J Acquir Immune Defic Syndr. 2012;61(5):574-80.

26. Tripathi A, Youmans E, Gibson JJ, Duffus WA. The impact of retention in early HIV medical care on viro-immunological parameters and survival: a statewide study. AIDS Res Hum Retroviruses. 2011;27(7):751-8.

27. Yehia BR, French B, Fleishman JA, Metlay JP, Berry SA, Korthuis PT, Agwu AL, Gebo KA, HIV Research Network. Retention in care is more strongly associated with viral suppression in HIV-infected patients with lower versus higher CD4 counts. J Acquir Immune Defic Syndr. 2014;65(3):333-9. https://doi.org/10.1097/QAl.0000000000000023.

28. Beach MC, Keruly J, Moore RD. Is the quality of the patient-provider relationship associated with better adherence and health outcomes for patients with HIV? J Gen Intern Med. 2006;21(6):661-5.

29. Lailulo Y, Kitenge M, Jaffer S, Aluko O, Nyasulu PS. Factors associated with antiretroviral treatment failure among people living with HIV on antiretroviral therapy in resource-poor settings: a systematic review and metaanalysis. Syst Rev. 2020;9(1):292. https://doi.org/10.1186/ s13643-020-01524-1.

30. The Impact of Employment on HIV Treatment Adherence. International Labour Office, Geneva, 2013. wcms_230625.pdf (reliefweb.int)

31. Rosen S, Ketlhapile M. Cost of using a patient tracer to reduce loss to follow-up and ascertain patient status in a large antiretroviral 
therapy program in Johannesburg, South Africa. Trop Med Int Health. 2010;15(s1):98-104.

32. Fonsah JY, Njamnshi AK, Kouanfack C, Qiu F, Njamnshi DM, Tagny CT, Nchindap E, Kenmogne L, Mbanya D, Heaton R, Kanmogne GD. Adherence to antiretroviral therapy (ART) in Yaoundé-Cameroon: association with opportunistic infections, depression, ART regimen and side effects. PLoS ONE. 2017;12(1):e0170893. https://doi.org/10.1371/journal.pone. 0170893.

33. Fielden SJ, Rusch ML, Yip B, Wood E, Shannon K, Levy AR, Montaner JS, Hogg RS. Nonadherence Increases the risk of hospitalization among
HIV-infected antiretroviral naive patients started on HAART. J Int Assoc Physicians AIDS Care (Chic). 2008;7(5):238-44. https://doi.org/10.1177/ 1545109708323132.

\section{Publisher's Note}

Springer Nature remains neutral with regard to jurisdictional claims in published maps and institutional affiliations.
Ready to submit your research? Choose BMC and benefit from:

- fast, convenient online submission

- thorough peer review by experienced researchers in your field

- rapid publication on acceptance

- support for research data, including large and complex data types

- gold Open Access which fosters wider collaboration and increased citations

- maximum visibility for your research: over 100M website views per year

At BMC, research is always in progress.

Learn more biomedcentral.com/submissions 